\title{
Environmental Assessment of Some Heavy Metals Pollution in Street Dust in the Industrial Areas of Ahvaz
}

\author{
Mandana Kianpor ${ }^{1}$, Khoshnaz Payandeh (D) ${ }^{1,}{ }^{*}$ and Navid Ghanavati ${ }^{1}$ \\ ${ }^{1}$ Department of Soil Science, Ahvaz Branch, Islamic Azad University, Ahvaz, Iran \\ "Corresponding author: Assistant Professor, Department of Soil Science, Ahvaz Branch, Islamic Azad University, Ahvaz, Iran. Emails: khpayandeh@iauahvaz.ac.ir; \\ cmp1391@yahoo.com
}

Received 2018 December 08; Revised 2019 May 28; Accepted 2019 June 03.

\begin{abstract}
Background: High concentrations of heavy metals in street dust are considered to be a serious risk to human health and the environment. Therefore, investigating the concentration of heavy metals to monitor pollution and preserve the quality of the environment is essential.

Objectives: This study aimed to examine the concentration, enrichment factor (EF), pollution index (PI), and Nemrow integrated pollution index (NIPI) of potentially heavy metals including $\mathrm{Cr}, \mathrm{Cu}, \mathrm{Cd}, \mathrm{Pb}, \mathrm{Zn}, \mathrm{Ni}, \mathrm{V}, \mathrm{As}$, and $\mathrm{Co}$ in street dust in the industrial areas of Ahvaz.

Methods: A total of 29 dust samples were collected from sidewalks of main streets of industrial areas of Ahvaz and were analyzed by the inductively coupled spectroscopy (ICP-OES) method.

Results: The average concentration of heavy metals in Pb, Zn, Cu, Cr, Cd, Ni, V, As, and Co was respectively: 86, 999, 50, 57, 0.3, 58, 184, 6 , and $13(\mathrm{mg} / \mathrm{kg})$, respectively. The mean concentration of all heavy metals in the samples of dust in the industrial areas of Ahvaz was several times higher than that of baseline values. Based on the average EF in the study area, $\mathrm{Zn}$ and $\mathrm{Pb}$ have extremely high enrichment. In addition, $\mathrm{Zn}, \mathrm{V}$, and Pb, with the highest PI average, displayed high pollution. In addition, the evaluation of NIPI showed that $100 \%$ of samples have high pollution.

Conclusions: The source of pollution of studied metals was anthropogenic, such as urban industrial facilities, transport, vehicle traffic, and burning of fossil fuels in the studied area. Generally, some protective protocol are proposed to reduce the level of heavy metals pollution in the city of Ahvaz, such as environmental control of gases produced by industries and factories, increase of green space, conversion of liquid fuel to gaseous, and use of public transportation.
\end{abstract}

Keywords: Air Pollution, Heavy Metals, Nemrow Integrated Pollution Index, Street Dust

\section{Background}

Human activities result in environmental pollution, for example, through the release of various toxic metals containing copper, lead, cadmium, and arsenic to urban environments (1). The dust of the street is composed of solid particles deposited on the surface of the ground, which acts as a reservoir for the collection of short-lived environmental materials from the surrounding areas (2, 3 ). The concern about the problem of metal pollution in street dust in recent decades has increased and research efforts have been correspondingly increased on the issue. Moreover, natural resources, such as soil weathering, metals in street dust mainly consist of a range of human activities counting industrial emissions (chemical plants, power plants, coal combustion, industry Metallurgy, car repair shops, etc.), traffic (car exhaust, tire, brake lining wear and weathered street surfaces), domestic emissions, atmospheric depositions, surfaces of asphalt, and etc. $(4,5)$. Heavy metals are not degradable and stay in the dust/soil environment for a long time or they can be re-suspended in the atmosphere and pose as a potential hazard to human health (6). Toxic metals usually do not decompose; they can accumulate in body fatty tissues and can be toxic to the human central nervous system $(7,8)$. Environmental factors, including enrichment factor (EF), modified pollution indices, and potential ecological risk (PER) can be used to assess the pollution of heavy metals, the separation of different sources of heavy metals, human activity, and parent materials in dust (9). Ghanavati (10), for Abadan street dust, showed that concentrations of $\mathrm{Cu}, \mathrm{As}, \mathrm{Pb}, \mathrm{Zn}$, $\mathrm{Co}, \mathrm{Cd}, \mathrm{Ni}, \mathrm{Cr}$, with an exception of $\mathrm{V}$ were several times greater than that of the baseline (concentration in the earth's crust). These findings indicate that the high con- 
centrations of these elements are related to anthropogenic sources such as industrial activities, traffic, burning of fossil fuels, and also construction activities. In their study on street dust of Huainan, it was shown that contamination levels of $\mathrm{Cd}$ and $\mathrm{Hg}$ were moderate to high, while content of $\mathrm{Cu}, \mathrm{Pb}, \mathrm{Cr}, \mathrm{Co}, \mathrm{Sb}$, and As were generally low to moderate. Content of $\mathrm{Hg}$ and $\mathrm{Cd}$ were related with significant health hazard at $64.3 \%$ and $58.6 \%$ of sites, respectively (11). In their research on the street dust of northwest China, it was found that the geo-accumulation index (Igeo) recommended that $\mathrm{Cu}, \mathrm{Pb}, \mathrm{Cr}$, and $\mathrm{Cd}$ were significantly impacted by human activity, while $\mathrm{Zn}$ in street dust was of natural source. The comprehensive pollution index indicated that urban dust in Lanzhou has a high potential ecological risk (12). The city of Ahvaz has been qualified as a fast urbanization and industrialization in the last years. Industrial development as well as increasing population and number of vehicles in Ahvaz increased heavy metals deposition in street dust particles. Ahvaz city was one of those cities heavily polluted in the world (13). However, it is still not clear about the spatial distribution patterns and contamination levels of heavy metals in street dust in the industrial zones of Ahvaz.

\section{Objectives}

The objectives of the present study are to: (1) determine the concentration and source of heavy metals in street dust samples collected from industrial zones of Ahvaz, and (2) assess potentially heavy metals pollution in the street dust using enrichment factor and pollution index.

\section{Methods}

\subsection{Studied Area}

Ahvaz (31019'45" N and 48041'28"), the capital of Khuzestan province in Iran, with a population of approximately 1.32 million in 2016, is situated in South-West Iran bordering Iraq, Kuwait, and Saudi Arabia, whose deserts are the main source of dust events in the Middle East (14). The climate of study area, which is almost near the Persian Gulf, is arid and sultry and almost cold and rainy in the winter. Average temperature in the study area is $32^{\circ} \mathrm{C}$ in January, $38^{\circ} \mathrm{C}$ in April, and $49^{\circ} \mathrm{C}$ in July. The rainy season normally extends from late December to almost the end of March with an average annual rainfall of $213 \mathrm{~mm} /$ year. The altitude datum in industrial town is about $25 \mathrm{~m}$ above the sea level.

\subsection{Soil Sampling and Analytical Methods}

In July 2018, 29 street dust samples were collected from industrial areas of Ahvaz, such as the Piping Plant Company, the Steel Industry, and Karun industrial zone (Figure 1). Samples were collected in the dry season of the year to prevent rain from washing the heavy metals. The meteorological conditions were steady through the sampling with no rain had occurred during one month earlier to sample collection. About $500 \mathrm{~g}$ of composite street dust samples were mainly collected by sweeping an area of about $1 \times 2$ $\mathrm{m}^{2}$ from road pavement using a plastic brush. The samples were air-dried, passed through a 220 mesh $(63 \mu \mathrm{m})$, and stored in polyethylene bags. The metals of $\mathrm{Ni}, \mathrm{Pb}, \mathrm{Cu}, \mathrm{Zn}$, $\mathrm{Cd}, \mathrm{Cr}, \mathrm{Co}, \mathrm{As}$, and $\mathrm{V}$ were measured by inductively coupled plasma optical emission spectroscopy (ICP-OES, Model Varian735). The preparation of samples was accomplished by dissolution using four acids, $\mathrm{HCl}, \mathrm{HF}, \mathrm{HClO}_{4}$, and $\mathrm{HNO}_{3}(15)$. After weighing samples, $250 \mathrm{mg} \mathrm{HF}(8 \mathrm{~mL}) 40 \%$ and $\mathrm{HClO}_{4}$ ( $1 \mathrm{~mL}$ ) 70\% were added; after, the prepared solution was placed in a special container (Hot Box) in water for up to $200^{\circ} \mathrm{C}$ until a jelly solution is obtained. Then, $\mathrm{HCl}(3.75$ $\mathrm{mL}) 37 \%$ and $\mathrm{HNO}_{3}(1.25 \mathrm{~mL}) 65 \%$ was added and the solution was transferred to a volume of $25 \mathrm{~mL}$ and finally analyzed by ICP-OES device. Quality assurance (QA) and quality control $(\mathrm{QC})$ were measured by measuring control samples and repetitive samples (with accuracy of $4 \%$ to $6 \%$ ) and reference materials NIST 2710 [with accuracy 100\% $\pm 5 \%(n=$ 15)]. The accuracy of the repeat samples was $4 \%-6 \%$ and the precision was less than $5 \%$.

\subsection{Pollution Assessment}

\subsubsection{Enrichment Factor}

The enrichment factor (EF) is used to distinguish between anthropogenic or natural source of pollution and also to determine the degree of heavy metal pollution in the environment (16). The EF of a particular element in a given specimen is the ratio of the concentration of that element in that sample to the baseline concentration of the same element in the environment to which the corresponding specimen belongs. Enrichment factor (EF) was estimated as follows:

$$
E F=\frac{\left(\frac{C_{x}}{C_{r e f}}\right)_{\text {Sample }}}{\left(\frac{C_{x}}{C_{r e f}}\right)_{\text {Background }}}
$$

The $\left(C_{x} / C_{\text {ref }}\right)$ is the ratio of value of heavy metal $(\mathrm{mg} / \mathrm{kg})$ to the value of target heavy metal in the selected and background sample (15). $C_{\text {ref }}$ (concentration of reference element) is an element that has a completely geological source. In environmental research studies, $\mathrm{Zr}, \mathrm{Ti}, \mathrm{Fe}, \mathrm{Al}$, and Sr are commonly used as reference elements (17). In this 


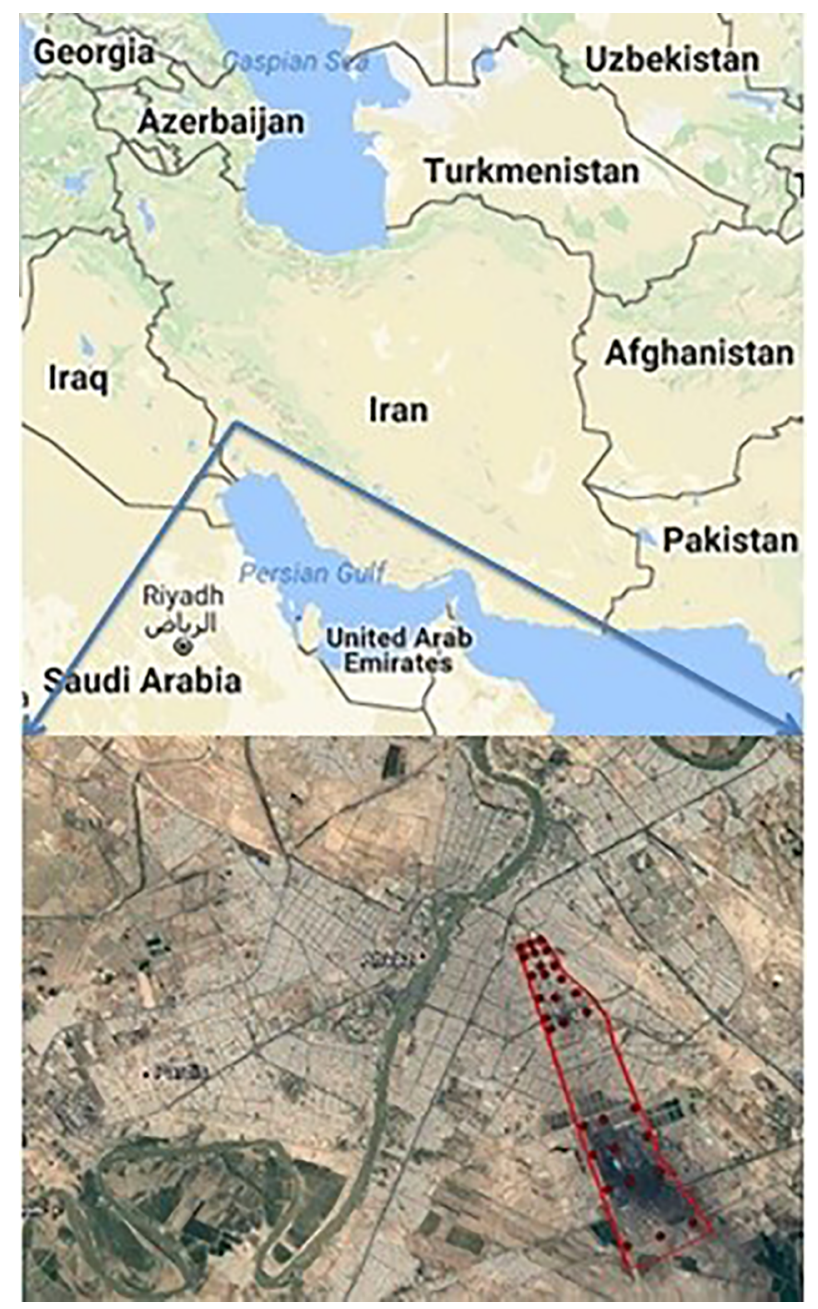

Figure 1. Location of street dust sample sites in the industrial zones of Ahvaz city

study, Al was considered as a reference element, because its anthropogenic sources of pollution are insignificant. This element is rich in earth's crust and is much less present in anthropogenic environmental pollution. Degree of pollution can be categorized in five classes (18): (1) $\mathrm{EF}<2$ (states deficiency to minimal enrichment), (2) $2 \leq \mathrm{EF} \leq 5$ (moderate enrichment), (3) $5 \leq \mathrm{EF} \leq 20$ (significant enrichment), (4) $20 \leq \mathrm{EF} \leq 40$ (very high enrichment), and (5) EF $>40$ (extremely high enrichment).

\subsubsection{Pollution Index (PI)}

The PI is used to assess the level of contamination, the formula is as follows:

$P I=\frac{C_{n}}{B_{n}}$
Where $C_{n}$ is measured concentration of element in dust, and $B_{n}$ is the concentration of the same heavy metal in the earth's crust. PI is classified into four groups: nonpollution $(\mathrm{PI} \leq 1)$, low pollution $(1<\mathrm{PI} \leq 2)$, moderate pollution $(2<\mathrm{PI} \leq 3)$, and high pollution (PI $>3)(19)$.

\subsubsection{Nemerow Integrated Pollution Index}

A Nemerow pollution index(NIPI) was applied to assess the general quality of the soil and dust environments and was calculated as:

$N I P I=\sqrt{\frac{P I_{\text {imax }}^{2}+P I_{i a v e}^{2}}{2}}$

In which, $\mathrm{PI}_{\text {imax }}$ is the maximum value of the pollution index for each heavy metal, and $\mathrm{PI}_{\text {iave }}$ is the average value of the pollution index for each heavy metal. The advantage of NIPI over other indexes is that it allows determining the pollution risk of all metals in the study area (20). The NIPI was classified as: non-pollution (NIPI $\leq 0.7$ ), warning line of pollution $(0.7<\mathrm{NIPI} \leq 1)$, low level of pollution $(1<\mathrm{NIPI}$ $\leq 2)$, moderate level of pollution $(2<\mathrm{NIPI} \leq 3)$, and high level of pollution (NIPI > 3).

\subsection{Statistical Analysis}

Statistical analyses of the data were carried out using the statistical software package SPSS version 22.0 for Windows and calculations of the indicators using the Excel software.

\section{Results}

\subsection{Heavy Metals Concentration}

Summary concentration data for heavy metals in street dust from industrial zones of Ahvaz is compared to upper continental crust (UCC) values in Table $1(21,22)$. The concentration value $(\mathrm{mg} / \mathrm{kg}$ ) of heavy metals in street dust samples ranged as follows: $\mathrm{Pb}, 35$ - 332 (average: 86), Zn, 112 - 7194 (average: 999), Cu, 25 - 111 (average: 50), Cr, 42 149 (average: 57), Cd, 0.3 - 0.60 (average: 0.3), Ni, 44 - 81 (average: 58), V, 60 - 654 (average: 184), As, 4 - 8 (average: 6 ), and Co, 8 - 19 (average: 13 ) $\mathrm{mg} / \mathrm{kg}$. The mean concentrations of all heavy metals were several times higher than the baseline concentration (i.e., concentration in the earth's crust) indicating possible anthropogenic sources such as Khuzestan Steel Co., Carbon Black Co., Rolling Pipe Co., Kavian Rolling Co., Sepanta and Parisaz factories, and industrial workshops in the studied region. 


\begin{tabular}{|c|c|c|c|c|}
\hline Heavy Metal & Min - Max & Mean \pm SD & Skewness & Upper Crust Content $^{\mathbf{a}}$ \\
\hline $\mathbf{P b}$ & $35-332$ & $86 \pm 62$ & 2.7 & 15 \\
\hline Zn & $112-7194$ & $999 \pm 2099$ & 2.7 & 31 \\
\hline $\mathrm{Cu}$ & $25-111$ & $45 \pm 22$ & 1.6 & 29 \\
\hline $\mathbf{C r}$ & $42-149$ & $57 \pm 20$ & 3.6 & 35 \\
\hline Cd & $0.3-0.6$ & $0.3 \pm 0.1$ & 2.1 & 0.09 \\
\hline $\mathbf{N i}$ & $44-81$ & $58 \pm 9$ & 0.5 & 20 \\
\hline $\mathbf{V}$ & $60-654$ & $184 \pm 143$ & 1.8 & 60 \\
\hline As & $4-8$ & $6 \pm 1$ & 0.7 & 4.8 \\
\hline Co & $8-19$ & $13 \pm 3$ & 0.6 & 10 \\
\hline
\end{tabular}

${ }^{\mathrm{a}}$ Source: reference No. (22).

\subsection{Enrichment Factor (EF)}

Upper crust (UCC) values were applied as background concentrations for heavy metal enrichment factors (EF) calculations, as reported in previous studies $(23,24)$. The enrichment factor (EF) values for each of the heavy metals are presented in Table 2. The range of EF values for $\mathrm{Pb}, \mathrm{Zn}, \mathrm{Cu}$, Cr, Cd, Ni, V, As, and Co were 20 - 235, 26 - 1280, 6 - 33, 4 - 12, 10 -36, 17 - 44, 7 -106, 9 - 24, and 7-21, respectively. The average EF values decreased as follows: $\mathrm{Zn}(209)>\mathrm{Pb}(55)>\mathrm{V}(27)>$ $\mathrm{Ni}(25)>\mathrm{Cu}(15)>\mathrm{Cd}(14.6)>\mathrm{As}(14)>\mathrm{Co}(11)>\mathrm{Cr}(5)$. Accordingly, $\mathrm{Cu}, \mathrm{Cd}, \mathrm{As}, \mathrm{Co}$, and $\mathrm{Cr}$ have high enrichment (5 $\geq \mathrm{EF}<20$ ), while $\mathrm{V}$ and $\mathrm{Ni}$ have very high enrichment (20 $\leq \mathrm{EF}<40$ ). In addition, $\mathrm{Zn}$ and $\mathrm{Pb}$, due to having a mean EF higher than 40, have extremely high enrichment. These results indicate that the concentrations of heavy metals in dust samples were significantly affected by human activities.

\subsection{Pollution Index (PI)}

The pollution index (PI) values for each of the heavy metals are presented in Table 3. According to the trend of PI in dust samples: $\mathrm{Zn}(32)>\mathrm{Pb}(6)>\mathrm{V}(3.1)>\mathrm{Ni}(2.9)>\mathrm{Cu}(1.7)$ $>\mathrm{Cd}(1.69)>$ As (1.62) > Co (1.29) > Cr (0.64). The Cr mean showed no pollution, the $\mathrm{Cu}, \mathrm{Cd}$, As, and Co showed low pollution, and Ni showed moderate pollution. In addition, $\mathrm{Zn}, \mathrm{Pb}$, and $\mathrm{V}$, with the highest PI mean, showed high pollution. According to the PI of the heavy metals studied, $\mathrm{Cr}$ (100\%) had no pollution, $\mathrm{Cu}(70 \%)$, As (76\%), Co (79\%), and Cd (90\%) had low pollution, and $\mathrm{Ni}$ (59\%) had moderate pollution, while $\mathrm{Zn}(100 \%)$ and $\mathrm{Pb}$ (79\%) were found to have high pollution in the study area.

\subsection{Nemerow Integrated Pollution Index (NIPI)}

The Nemerow integrated pollution index (NIPI) in the studied samples is presented in Table 4. The advantage of this indicator is that the risk of pollution of all heavy metals is determined. The mean value of this indicator is 24 . The results of NIPI showed that $100 \%$ of the samples had high pollution.

\section{Discussion}

The average concentration of all heavy metals in the samples of dust in the industrial areas of Ahvaz was several times higher than that of baseline values, which indicated possible anthropogenic input of metals from large industrial plants such as Khuzestan Steel Co., Carbon Black Co., Rolling Pipe Co., Kavian Rolling Co., Sepanta and Parisaz factories, and industrial workshops in studied region. Assessment of heavy metal pollution in soils nearby the Kerman steel industry showed that the trend of EF in dust samples were: $\mathrm{Pb}>\mathrm{Zn}>\mathrm{Cd}>\mathrm{Fe}>\mathrm{Ni}>\mathrm{Cr}$. $\mathrm{EF}$ index also showed that $90 \%$ of the samples were moderately to significantly polluted with lead element. The average values of Cd and Cd showed low degree of pollution (25). Survey of heavy metals pollution in surface soils around the industrial town of Ahvaz showed that according to geochemical criteria such as index of geo-accumulation (Igeo), enrichment factor (EF), and pollution index (PI), the soils of the study area are considered to be moderately contaminated with respect to $\mathrm{Cr}, \mathrm{Ni}$, and $\mathrm{Pb}$, and uncontaminated with respect to $\mathrm{Co}, \mathrm{Cu}$, and $\mathrm{Zn}$. The calculated results of $\mathrm{EF}$, Igeo, and PI of heavy metals are as follows: $\mathrm{Ni}>\mathrm{Pb}>\mathrm{Cr}>\mathrm{Zn}$ $>\mathrm{Cu}>\mathrm{Co}(26)$. Assessment of heavy metals using pollution load index in the Zanjan zinc industrial town area indicate that the measured heavy metals contents with their maximum permissible limits in the soil showed that the studied soils are polluted with $\mathrm{Zn}, \mathrm{Pb}$, and $\mathrm{Cd}$; however, it was non-polluted with $\mathrm{Ni}$ and $\mathrm{Cu}$. Classification of observations, according to the contamination factor of stud- 


\begin{tabular}{|c|c|c|c|c|c|c|c|c|}
\hline \multirow{2}{*}{ Metals } & \multicolumn{3}{|c|}{ EF } & \multicolumn{5}{|c|}{ Number of Sample (\%) } \\
\hline & Min & Max & Mean & $\begin{array}{c}\text { Low } \\
\text { Enrichment }\end{array}$ & $\begin{array}{c}\text { Moderate } \\
\text { Enrichment }\end{array}$ & $\begin{array}{l}\text { Significant } \\
\text { Enrichment }\end{array}$ & $\begin{array}{l}\text { Very High } \\
\text { Enrichment }\end{array}$ & $\begin{array}{c}\text { Extremely } \\
\text { High } \\
\text { Enrichment }\end{array}$ \\
\hline $\mathbf{P b}$ & 20 & 235 & 55 & 0 & 0 & 0 & $13(45)$ & $16(55)$ \\
\hline Zn & 26 & 1280 & 209 & 0 & 0 & 0 & $5(17)$ & $24(83)$ \\
\hline $\mathrm{Cu}$ & 6 & 33 & 15 & 0 & 0 & $21(72)$ & $8(28)$ & 0 \\
\hline $\mathrm{Cr}$ & 4 & 12 & 5 & 0 & $16(55)$ & $13(45)$ & 0 & 0 \\
\hline Cd & 10 & 36 & 14.6 & 0 & 0 & $27(93)$ & $2(7)$ & 0 \\
\hline $\mathbf{N i}$ & 17 & 44 & 25 & 0 & 0 & $3(10)$ & $26(90)$ & 0 \\
\hline $\mathbf{V}$ & 7 & 106 & 27 & 0 & 0 & $17(59)$ & $7(24)$ & $5(17)$ \\
\hline As & 9 & 24 & 14 & 0 & 0 & $27(93)$ & $2(7)$ & 0 \\
\hline Co & 7 & 21 & 11 & 0 & 0 & $28(97)$ & $1(3)$ & 0 \\
\hline
\end{tabular}

\begin{tabular}{|c|c|c|c|c|c|c|c|}
\hline \multirow{2}{*}{ Metals } & \multicolumn{3}{|c|}{ PI } & \multicolumn{4}{|c|}{ Number of Sample (\%) } \\
\hline & Min & $\operatorname{Max}$ & Mean & No Pollution & Low Pollution & $\begin{array}{l}\text { Moderate } \\
\text { Pollution }\end{array}$ & High Pollution \\
\hline $\mathbf{P b}$ & 2.50 & 24 & 6 & 0 & 0 & $6(21)$ & $23(79)$ \\
\hline Zn & 3.61 & 232 & 32 & 0 & 0 & 0 & $29(100)$ \\
\hline $\mathrm{Cu}$ & 0.86 & 3.83 & 1.71 & $3(10)$ & $20(70)$ & $3(10)$ & $3(10)$ \\
\hline $\mathrm{Cr}$ & 0.47 & 1.66 & 0.64 & $28(97)$ & $1(3)$ & 0 & 0 \\
\hline Cd & 1.30 & 3 & 1.69 & 0 & $26(90)$ & $3(10)$ & 0 \\
\hline $\mathbf{N i}$ & 2.20 & 4.05 & 2.90 & 0 & 0 & $17(59)$ & $12(41)$ \\
\hline $\mathbf{v}$ & 1 & 11 & 3.06 & $1(3)$ & $11(38)$ & $8(28)$ & $9(31)$ \\
\hline As & 1 & 2.40 & 1.62 & $1(3)$ & $22(76)$ & $6(21)$ & 0 \\
\hline Co & 0.80 & 1.90 & 1.29 & $6(21)$ & $23(79)$ & 0 & 0 \\
\hline
\end{tabular}

Table 4. Nemerow Integrated Pollution Index (NIPI) for Heavy Metals in the Study Area

\begin{tabular}{cccccc}
\hline & NIPI & & \multicolumn{2}{c}{ Samples Pollution Level, No. (\%) } \\
\hline Min & Max & Mean & No Pollution & $\begin{array}{c}\text { Warning Line } \\
\text { Pollution }\end{array}$ & $\begin{array}{c}\text { Low Pollution } \\
\text { Moderate } \\
\text { Pollution }\end{array}$ \\
\hline 3 & 165 & 24 & 0 & 0 & 0 \\
\hline
\end{tabular}

ied heavy metals, showed that most of sampling points occurred in very high contamination class regarding $\mathrm{Zn}$ and $\mathrm{Pb}$ (65.9\% and 68.2\%, respectively) and in the medium contamination class regarding $\mathrm{Cd}, \mathrm{Cu}$, and $\mathrm{Ni}$ (57.7, 51.8 and $68.2 \%$, respectively). The mean $\mathrm{EF}$ values for $\mathrm{Zn}, \mathrm{Pb}, \mathrm{V}, \mathrm{Ni}$, $\mathrm{Cu}, \mathrm{Cd}, \mathrm{As}$, and $\mathrm{Co}$ in industrial zones of Ahvaz street dust samples were greater than 10 , which indicate that their source is mainly anthropogenic. However, the mean $\mathrm{EF}$ for heavy metal of $\mathrm{Cr}$ indicated that their source of pollution could be related to both natural sources, such as weathering. These results prove that the heavy metals can be related to industrial plants, vehicles tires, corrosion of met- als, and fossil fuel combustion (27). The highest enrichment factor (EF) and pollutant index (PI) in the study area are related to heavy metals of $\mathrm{Zn}$ and $\mathrm{Pb}$. Zinc is used as an activator in the rubber manufacturing process (28), widely utilized for corrosion protection of steel (29), and extensively used for soldering in the automotive industry (30). Whilst many studies show that the main source of $\mathrm{Pb}$ in street dust is from fuel additives for automobiles (31), the banned usage of leaded petrol in Ahvaz suggests alternative sources of $\mathrm{Pb}$ in street dust (29), such as in lubricating oils in motor vehicles or wear of brake linings from road vehicles (32). According to NIPI, $100 \%$ of the samples had 
high pollution. This result proposes that the dusts in this study area are significantly affected by human activities. Therefore, reducing the levels of heavy metals in order to prevent the potential hazard of these metals in industrial areas should be considered.

\subsection{Conclusions}

The concentration values, enrichment factors, pollution index, and ecological risk of the potentially heavy metals ( $\mathrm{Pb}, \mathrm{Zn}, \mathrm{Cu}, \mathrm{Cd}, \mathrm{Cr}, \mathrm{As}, \mathrm{Ni}, \mathrm{Co}$, and $\mathrm{V}$ ) in the industrial areas of Ahvaz street dust were determined and concentration of all heavy metals in street dust was greater than their corresponding UCC, demonstrating potential anthropogenic sources (industrial plants, vehicular traffic, abrasion of tires, and asphalt pavement). The average EF values decreased as follows: $\mathrm{Zn}>\mathrm{Pb}>\mathrm{V}>\mathrm{Ni}>\mathrm{Cu}>\mathrm{Cd}$ $>$ As $>$ Co $>$ Cr. The evaluation of NIPI showed that $100 \%$ of samples have high pollution. Therefore, some protective measures have been proposed to reduce the amount of heavy metals pollution in the city, such as environmental control of gases produced by industries and factories, increasing green space, converting liquid fuel into natural gas, and using public transport.

\section{Acknowledgments}

The authors thank all faculty members and other participants who took part in the study.

\section{Footnotes}

Authors' Contribution: All authors are equally involved. Conflict of Interests: Authors declared no conflict of interest.

Ethical Approval: This article comes from a Master's thesis of soil science. It has been registered with code 10650202952002 at Research Committee of the Islamic Azad University.

Funding/Support: No grants were received from any funding agencies in the public, commercial, or profit sectors.

\section{References}

1. Wei X, Gao B, Wang P, Zhou H, Lu J. Pollution characteristics and health risk assessment of heavy metals in street dusts from different functional areas in Beijing, China. Ecotoxicol Environ Saf. 2015;112:186-92. doi:10.1016/j.ecoenv.2014.11.005. [PubMed: 25463870].

2. Amato F, Favez O, Pandolfi M, Alastuey A, Querol X, Moukhtar S, et al. Traffic induced particle resuspension in Paris: Emission factors and source contributions. Atmos Environ. 2016;129:114-24. doi: 10.1016/j.atmosenv.2016.01.022.
3. Zhao H, Shao Y, Yin C, Jiang Y, Li X. An index for estimating the potential metal pollution contribution to atmospheric particulate matter from road dust in Beijing. Sci Total Environ. 2016;550:167-75. doi 10.1016/j.scitotenv.2016.01.110. [PubMed: 26815293].

4. Tang R, Ma K, Zhang Y, Mao Q. The spatial characteristics and pollution levels of metals in urban street dust of Beijing, China. Applied Geochemistry. 2013;35:88-98. doi: 10.1016/j.apgeochem.2013.03.016.

5. Lu X, Wu X, Wang Y, Chen H, Gao P, Fu Y. Risk assessment of toxic metals in street dust from a medium-sized industrial city of China. Ecotoxicol Environ Saf. 2014;106:154-63. doi: 10.1016/j.ecoenv.2014.04.022. [PubMed: 24840878].

6. Ghanavati N, Nazarpour A, Watts MJ. Status, source, ecological and health risk assessment of toxic metals and polycyclic aromatic hydrocarbons (PAHs) in street dust of Abadan, Iran. Catena. 2019;177:246-59. doi: 10.1016/j.catena.2019.02.022.

7. Denier X, Hill EM, Rotchell J, Minier C. Estrogenic activity of cadmium, copper and zinc in the yeast estrogen screen. Toxicol In Vitro. 2009;23(4):569-73. doi: 10.1016/j.tiv.2009.01.006. [PubMed: 19490851].

8. Babaei H, Ghanavati N, Nazarpour A. [Contamination level of mercury in the street dust of Ahvaz city and its spatial distribution].JWater Soil Sci. 2018;22(3):249-59. Persian. doi:10.29252/jstnar.22.3.249.

9. Ghanavati N, Nazarpour A, De Vivo B. Ecological and human health risk assessment of toxic metals in street dusts and surface soils in Ahvaz, Iran. Environ Geochem Health. 2019;41(2):875-91. doi: 10.1007/s10653-018-0184-y. [PubMed: 30209637].

10. Ghanavati N. [Human health risk assessment of heavy metals in street dust in Abadan]. Iran J Health Environ. 2018;11(1):63-74. Persian.

11. Tang Z, Chai M, Cheng J, Jin J, Yang Y, Nie Z, et al. Contamination and health risks of heavy metals in street dust from a coalmining city in eastern China. Ecotoxicol Environ Saf. 2017;138:83-91. doi: 10.1016/j.ecoenv.2016.11.003. [PubMed: 28012369].

12. Jiang Y, Shi L, Guang AL, Mu Z, Zhan H, Wu Y. Contamination levels and human health risk assessment of toxic heavy metals in street dust in an industrial city in Northwest China. Environ Geochem Health. 2018;40(5):2007-20. doi: 10.1007/s10653-017-0028-1. [PubMed 29027046].

13. Nazarpour A, Ghanavati N, Watts MJ. Spatial distribution and human health risk assessment of mercury in street dust resulting from various land-use in Ahvaz, Iran. Environ Geochem Health. 2018;40(2):693704. doi: 10.1007/s10653-017-0016-5. [PubMed: 28865066].

14. Ghanavati N, Nazarpour A, Babaenejad T. [Assessing the ecological and health risks of some heavy metals in roadside soil of Ahvaz].J Sch Publ Health Inst Publ Health Res. 2019;16(4):373-90. Persian.

15. Yongming $\mathrm{H}$, Peixuan D, Junji C, Posmentier ES. Multivariate analysis of heavy metal contamination in urban dusts of Xi'an, Central China. Sci Total Environ. 2006;355(1-3):176-86. doi: 10.1016/j.scitotenv.2005.02.026. [PubMed: 15885748].

16. Lu X, Zhang X, Li LY, Chen H. Assessment of metals pollution and health risk in dust from nursery schools in Xi'an, China. Environ Res. 2014;128:27-34. doi: 10.1016/j.envres.2013.11.007. [PubMed: 24407476].

17. Abrahim GM, Parker RJ. Assessment of heavy metal enrichment factors and the degree of contamination in marine sediments from Tamaki Estuary, Auckland, New Zealand. Environ Monit Assess. 2008,136(1-3):227-38. doi: 10.1007/s10661-007-9678-2. [PubMed: 17370131].

18. Namaghi HH, Karami GH, Saadat S. A study on chemical properties of groundwater and soil in ophiolitic rocks in Firuzabad, east of Shahrood, Iran: with emphasis to heavy metal contamination. Environ Monit Assess. 2011;174(1-4):573-83. doi: 10.1007/s10661-010-1479-3. [PubMed: 20464631].

19. Brown JN, Peake BM. Sources of heavy metals and polycyclic aromatic hydrocarbons in urban stormwater runoff. Sci Total Environ. 2006;359(1-3):145-55. doi: 10.1016/j.scitotenv.2005.05.016. [PubMed: 16014309]. 
20. Yang Z, Lu W, Long Y, Bao X, Yang Q. Assessment of heavy metals contamination in urban topsoil from Changchun City, China.J Geochem Explor. 2011;108(1):27-38. doi: 10.1016/j.gexplo.2010.09.006.

21. Kabata-Pendias A. Trace elements in soils and plants. 4th ed. CRC press; 2010. doi: 10.1201/b10158.

22. Rudnick RL, Gao S. Composition of the continental crust. Treatise Geochem. 2003;3:1-64. doi:10.1016/bo-08-043751-6/03016-4.

23. Kartal S, Aydin Z, Tokalioglu S. Fractionation of metals in street sediment samples by using the BCR sequential extraction procedure and multivariate statistical elucidation of the data. J Hazard Mater. 2006;132(1):80-9. doi: 10.1016/j.jhazmat.2005.11.091. [PubMed: 16466857].

24. Reimann C, de Caritat P. Distinguishing between natural and anthropogenic sources for elements in the environment: regional geochemical surveys versus enrichment factors. Sci Total Environ. 2005;337(13):91-107. doi: 10.1016/j.scitotenv.2004.06.011. [PubMed: 15626382].

25. Sistani N, Moeinaddini M, Khorasani N, Hamidian AH, Ali-Taleshi MS, Azimi Yancheshmeh R. [Heavy metal pollution in soils nearby Kerman steel industry: metal richness and degree of contamination assessment]. Iran J Health Environ. 2017;10(1):75-86. Persian.

26. Pournia M, Moosavi MH, Jassemi Z. [Survey of heavy metals pollution in surface soils around the industrial town of Ahvaz 2].J Environ Scie
Tech. 2016;17(4):23-33. Persian.

27. Kong S, Lu B, Ji Y, Bai Z, Xu Y, Liu Y, et al. Distribution and sources of polycyclic aromatic hydrocarbons in size-differentiated resuspended dust on building surfaces in an oilfield city, China. Atmos Environ. 2012;55:7-16. doi: 10.1016/j.atmosenv.2012.03.044.

28. Smolders E, Degryse F. Fate and effect of zinc from tire debris in soil. Environ Sci Technol. 2002;36(17):3706-10. doi: 10.1021/es025567p. [PubMed: 12322741].

29. Deletraz G. [Géographie des risques environnementaux liés aux transports routiers en montagne. Incidences des emissions d'oxydes d'azote en vallées d'Aspe et de Biriatou (Pyrénées)] [dissertation]. Université de Pau et des Pays de l'Adour; 2002. French.

30. Howe PD, Watts P; World Health Organization; Chemical Safety Team and International Programme on Chemical Safety. Tin and inorganic tin compounds. World Health Organization; 2005.

31. Zhang X, Yang L, Li Y, Li H, Wang W, Ye B. Impacts of lead/zinc mining and smelting on the environment and human health in China. Environ Monit Assess. 2012;184(4):2261-73. doi: 10.1007/s10661-011-21156. [PubMed: 21573711]

32. Smichowski P, Gómez D, Frazzoli C, Caroli S. Traffic-related elements in airborne particulate matter. Appl Spectros Rev. 2007;43(1):23-49. doi: 10.1080/05704920701645886 